\title{
The Effect of Pori Hole Distance Variation on Infiltration Capacity in Sandy Clay Soil Sample Drainage Channels
}

\author{
Fenti Daud Sindagamanik*, Sukmasari Antaria, Nenny T Karim, Fauzan Hamdi, Asriany \\ Department of Civil Irrigation, Faculty of Engineering, University of Muhammadiayah Makassar, Indonesia
}

Received November 22, 2020; Revised April 3, 2021; Accepted April 26, 2021

\section{Cite This Paper in the following Citation Styles}

(a): [1] Fenti Daud Sindagamanik, Sukmasari Antaria, Nenny T Karim, Fauzan Hamdi, Asriany, "The Effect of Pori Hole Distance Variation on Infiltration Capacity in Sandy Clay Soil Sample Drainage Channels," Civil Engineering and Architecture, Vol. 9, No. 3, pp. 836-841, 2021. DOI: 10.13189/cea.2021.090325.

(b): Fenti Daud Sindagamanik, Sukmasari Antaria, Nenny T Karim, Fauzan Hamdi, Asriany (2021). The Effect of Pori Hole Distance Variation on Infiltration Capacity in Sandy Clay Soil Sample Drainage Channels. Civil Engineering and Architecture, 9(3), 836-841. DOI: 10.13189/cea.2021.090325.

Copyright $\bigcirc 2021$ by authors, all rights reserved. Authors agree that this article remains permanently open access under the terms of the Creative Commons Attribution License 4.0 International License

\begin{abstract}
The infiltration capacity will decrease if the number of infiltration fields decreases. This results in increased surface runoff or inundation. The planning concept that creates a groundwater infiltration area in drainage will be able to reduce inundation in drainage. Pore Cylinder Hole is a water infiltration method by increasing water absorption in the soil. The aim of the study was to determine the effect of pore-hole spacing on infiltration capacity in pore-cylindrical drainage and to determine how much infiltration discharge due to variations in hole spacing using three levels of pore cylinder heights. This research was conducted using a pore-cylindrical drainage model and spacing the biopore holes and flowing water on the drainage surface. From the results of this study, it was found that the effect of the hole distance on the infiltration discharge, the closer the hole to the pore cylinder, the greater the infiltration discharge that occurs, it can be proven from the results of analysis of research data, for a flow rate of $400 \mathrm{~cm}^{3} / \mathrm{sec}, \mathrm{Qf}=35.1 \mathrm{~cm}^{3} / \mathrm{sec}$. for spacing of holes $16 \mathrm{~cm}$ ); $\mathrm{Qf}=31.9 \mathrm{~cm}^{3} / \mathrm{s}$ (to describe $32 \mathrm{~cm}$ holes); and Qf $=3.13 \mathrm{~cm}^{3} / \mathrm{s}$ (for spacing of $16 \mathrm{~cm}$ holes).
\end{abstract}

Keywords Infiltration, Pore Cylinder Hole, Infiltration Debit

\section{Introduction}

The increase in population is accompanied by further development in the city of Makassar. Development that is not evenly distributed and not environmentally sound results in loss of catchment areas and flooding during the rainy season. Construction of drainage that is not environmentally sound is also a major factor in flooding. Drainage plays an important role in regulating water supply for flood prevention. Drainage means flowing, draining, disposing, or diverting water. In general, drainage is defined as a series of water structures that function to reduce and / or remove excess water from an area or land, therefore, land can be used optimally [15]. Drainage is also defined as an attempt to control the quality of groundwater in relation to sanitation [15].

Due to the loss of catchment areas, poor drainage systems and the general lack of public awareness by disposing of rubbish in drainages or canals, drainage becomes clogged and overflows as a result almost every year when the rainy season comes, floods occur around residential areas such as the Minasaupa road and on the main roads in Makassar city such as on the AP Petarani street and Sultan Alauddin Makassar. The government's efforts in overcoming floods still need to be improved, dredging canals and enlarging drainage channels is deemed insufficient to cope with flooding which every year is a subscription for Makassar residents. The conventional drainage concept that drains wastewater as soon as possible needs to be revised by flowing naturally (moderately), as a result, it does not cause flooding downstream. 
This underlies the need for a new design in the manufacture of drainage that not only functions to accommodate and drain water but is also able to absorb water or help the infiltration process to reduce puddles in drainage and increase underground water reserves. Infiltration itself is the vertical movement of water into the ground from the surface [1] [8]. Infiltration causes water to be available for plant growth and groundwater is replenished. The terms infiltration and percolation are often used and interchangeable, but they actually define different things. Percolation is specifically used to describe the movement of water between layers in the soil, while infiltration is used to describe the movement of water from the surface into the topsoil [9].

An environmentally friendly drainage design, which is making drainage with Biopore Infiltration Holes (BIH) is a water infiltration method aimed at overcoming waterlogging by increasing water absorption in the soil, increasing water absorption in the soil by making holes at the bottom of the drainage [3] [5]. The beginning of this planning required laboratory experiments by making drainage simulations with biopore infiltration holes at the base. To find out the amount of infiltration discharge, from the variant of the pore cylinder distance.

The results of this study are expected to provide a new drainage design that can reduce inundation in the drainage during rainy season.

\section{Research Method}

This research was conducted at the Hydrology Laboratory of the Engineering Faculty, Muhammadiyah
University of Makassar. Soil characteristic tests were carried out in the laboratory of the Faculty of Engineering, University of Muhammadiyah Makassar and in the laboratory of the Faculty of Engineering, Hasanuddin University Makassar.

\subsection{Research Plan Model}

\subsubsection{Sketch of Pore-cylinder Drainage Channel Model}

This model consists of two containers, namely the one block model container which functions as a water storage container and the second block container which functions as a soil storage container made of acrylic. The channel model is shown in Fig. 1.

\subsubsection{Sketch of a Model of a Pore Cylinder Drainage Channel}

In this design, the hole spacing will vary, namely $\mathrm{d} 1=$ $16 \mathrm{~cm}, \mathrm{~d} 2=32 \mathrm{~cm}, \mathrm{~d} 3=48 \mathrm{~cm}$. The working method of the variation of the holes is to close the pore holes according to the distance you want to observe, meaning that these pore-cylinder holes are effective because they can be lifted and installed. The pore hole model in drainage is shown in Fig. 2.

\subsubsection{Cut-out Pore Cylindrical Drainage Model}

This pore cylinder hole has a diameter of $8 \mathrm{~cm}$ with a pore cylinder height, namely $\mathrm{h} 1=5 \mathrm{~cm}, \mathrm{~h} 2=10 \mathrm{~cm}, \mathrm{~h} 3=$ $15 \mathrm{~cm}$ below the ground surface. This pore cylindrical channel uses a ram wire containing coarse aggregates that passes the no.16 screening test. Cylinder height models are shown in Figs. 3.

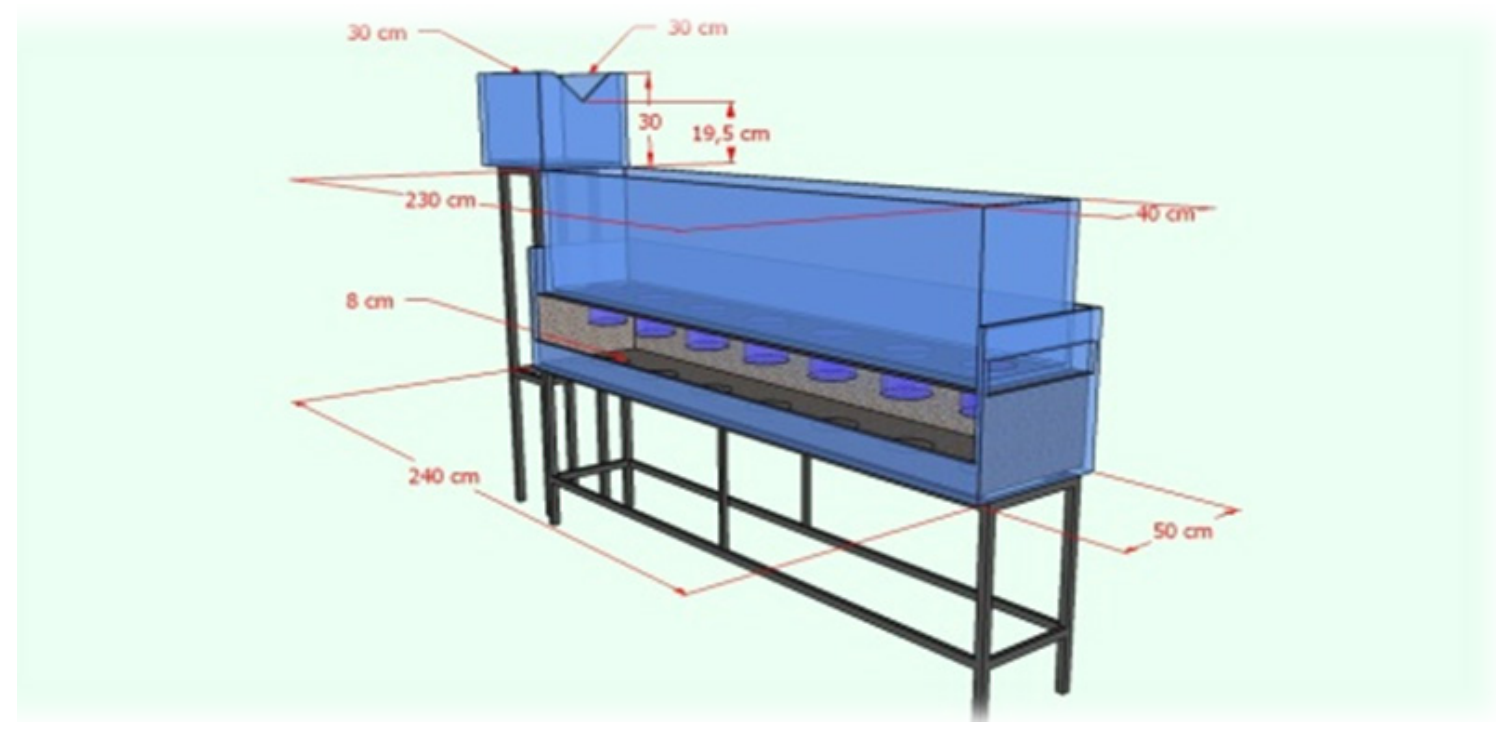

Figure 1. Pore Cylindrical Drainage Model 


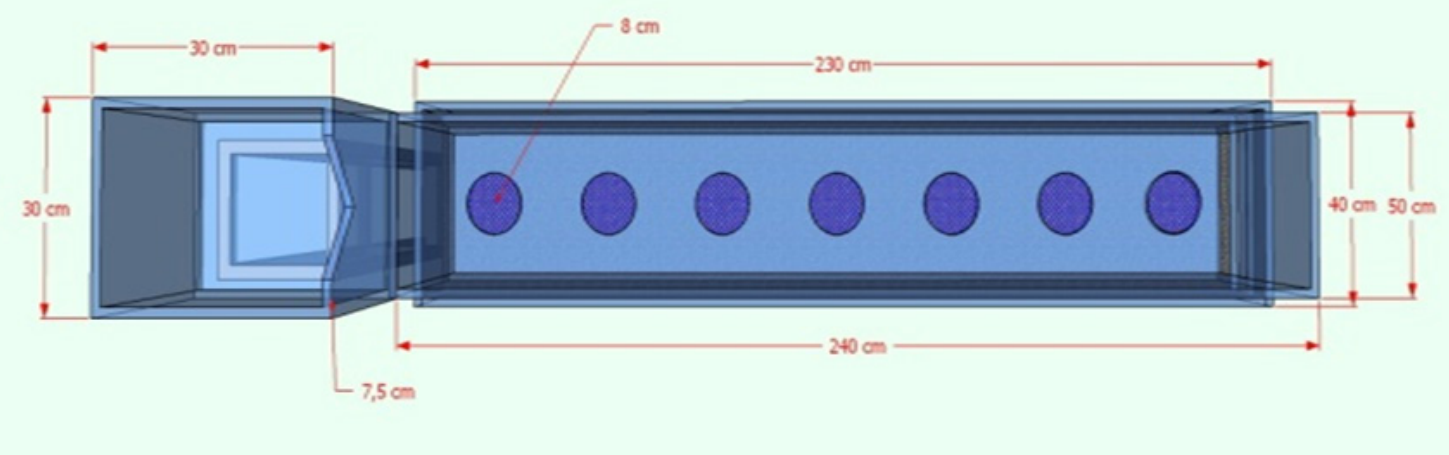

Figure 2. Top view of the Pore Cylindrical Drainage Model

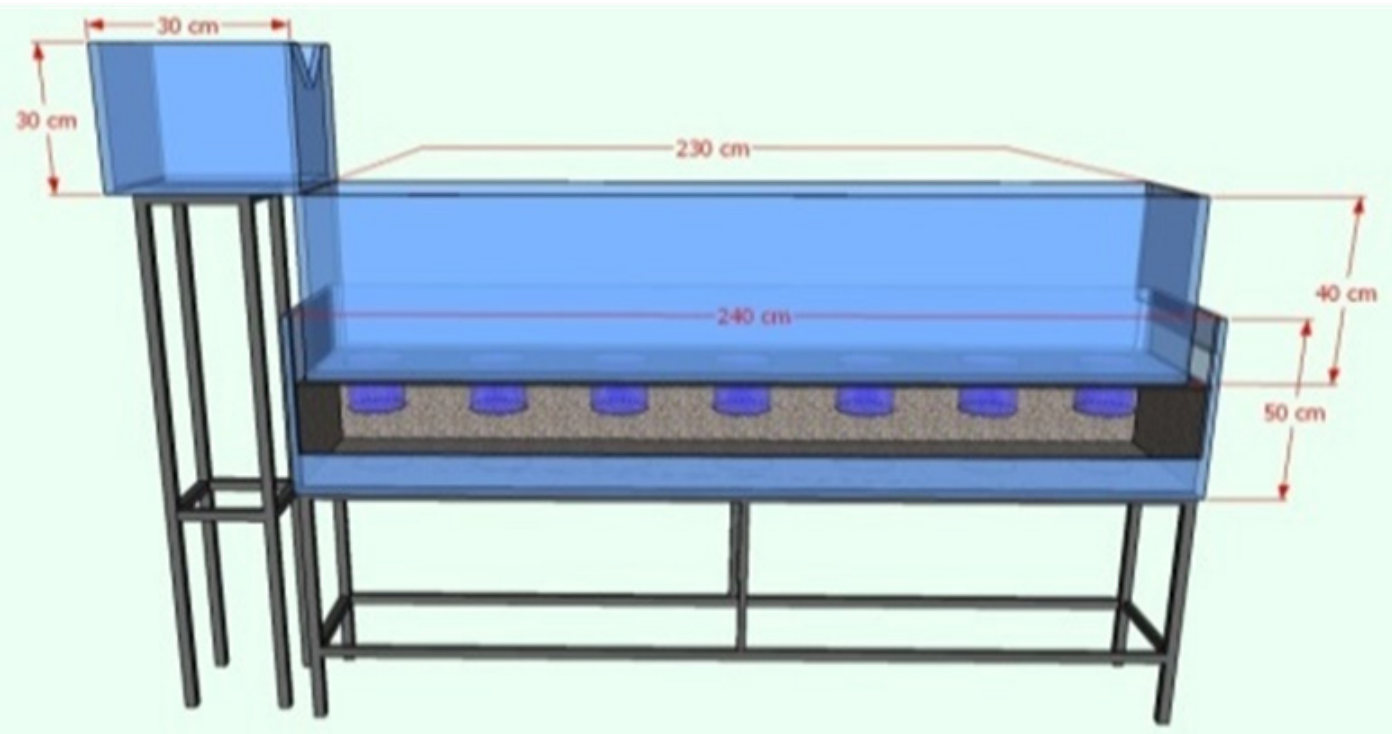

Figure 3. Cut-out of Pore Cylindrical Drainage Model

\subsection{Preparation of Tools and Materials}

Simulated pore cylinder drainage is made of acrylic with a hollow iron frame. The tools and materials that assist in the research are containers to accommodate run off water, measuring cups to accommodate infiltration, wire ropes for pore cylinders, stopwatches for the duration of the study, water pumps, sample soil, which was sandy loam, water and others.

\subsection{Research Procedures}

\subsubsection{Prepare a Pore Cylinder Drainage Model}

Make drainage designs and Thomson door models are as shown in Figure 4 made of acrylic and hollow iron to support drainage channels.

\subsubsection{Carry out Soil Mixing According to Soil Composition}

\subsubsection{Soil characteristics}

Soil texture is the visual appearance of a soil based on the qualitative composition of the size of the soil grains in a certain soil mass [2]. The soil texture class is divided into three basic classes, which are, sand, loam, and clay [14]. The sand group includes soil which contains at least $70 \%$ of its weight / weight as sand [14]. The clay group is a soil that contains at least $35 \%$ clay. As long as the percentage of clay is more than $40 \%$, the properties of the soil are determined by its clay content and can be distinguished into sandy clay and dusty clay [14]. The clay group itself ideally consists of sand, dust, and clay which consider the properties of light and weight in equal proportions. Soils with high sand fraction have high water permeability and aeration; on the other hand, soils with high clay fraction have low water absorption ability [14].

Soil characteristics used in this study is soil from the results of grain size inspection with sieve tests of 40,100 and 200. Soil characteristics are classified, namely sand, dust and clay determined based on the size division of soil fractions according to the United States Department of Agriculture (USDA) 1938 System [9] [14]. Soil characteristics greatly affect the infiltration rate, the larger 
the soil grain, the faster the infiltration rate [13].

From the classification, for clay sand soil it takes $75 \%$ sand, $15 \%$ dust and $10 \%$ clay [14].

\subsubsection{Bulk Density}

Bulk density is the weight of the whole dry soil divided by the volume of soil expressed in $\mathrm{gr} / \mathrm{cm}^{3}$. The bulk density obtained after testing is $1.84 \mathrm{gr} / \mathrm{cm}^{3}$ of sandy loam soil. Based on the bulk density of the soil sample obtained, the weight of the soil needed is attained.

\subsubsection{Flow Debit Management}

The discharge in this study uses the Thomson door gate as shown in Figure 4. To achieve the desired flow rate, the Thomson door device calibration is carried out to determine the flow rate. Calibration data collecting was carried out 5 times running every 5 minutes for 25 minutes.

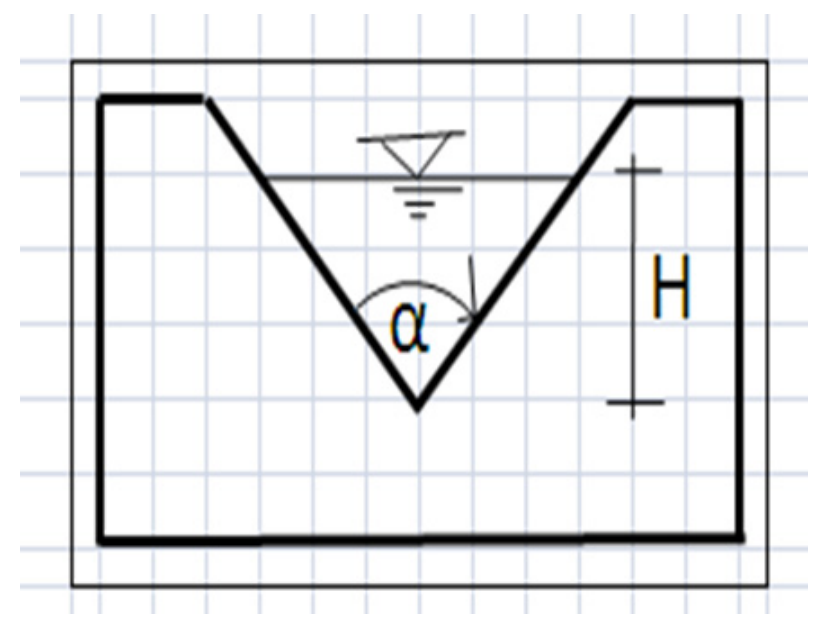

Figure 4. Thomson's door [16]

The amount of debit passing through the Thomson door is calculated by the formula:

$$
Q=\frac{8}{15} C_{d} \operatorname{tg} \frac{\alpha}{2} \sqrt{2 g} H^{5 / 2}
$$

Where:

$\mathrm{Q}=$ Flow rate $(1 / \mathrm{s})$

$\mathrm{C} \mathrm{d}$ = flow coefficient; will be obtained from the experimental results on the Thomson door.

$\alpha=$ Angle of vapor triangle

$\mathrm{g}=$ Acceleration due to gravity

$\mathrm{H}=$ Height of water at Thomson's door

\subsection{Data Analysis}

The results of the measurement of infiltration discharge in the perforated drainage in the laboratory are tabulated and graphically depicted and analyzed descriptively, qualitatively and quantitatively.

\subsection{Research Flowchart}

The stages carried out in this study can be seen in Figure.

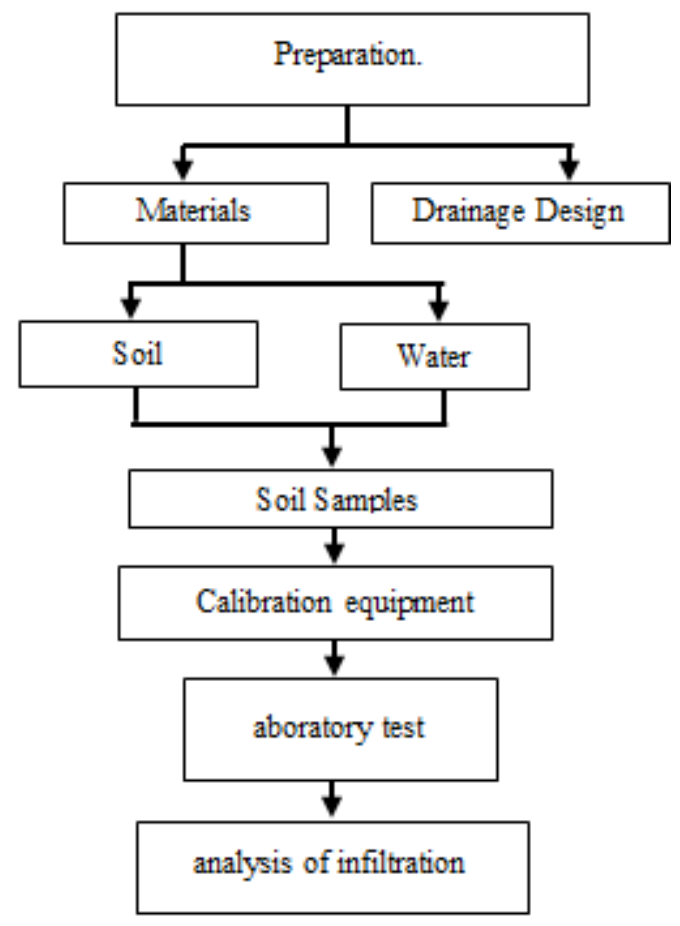

Picture 5. Research Flow Chart

\section{Results and Discussion}

\subsection{Soil Texture Samples}

As infiltration media at the bottom of the canal used sandy loam samples, from the results of soil texture inspection, the composition of soil samples was obtained. From the above classification, clay sand requires $75 \%$ sand, $15 \%$ dust and $10 \%$ clay. And obtained soil density is 1.84 $\mathrm{gr} / \mathrm{cm}^{3}$.

Based on the density of the soil sample, the amount of soil weight needed to fill the sample tub is shown in Table 1.

Table 1. Required Soil Weight

\begin{tabular}{ccc}
\hline $\begin{array}{c}\text { Hole Spacing } \\
(\mathbf{~ c m})\end{array}$ & $\begin{array}{c}\text { Pore } \\
\text { Cylinder } \\
\text { Height }(\mathbf{c m})\end{array}$ & $\begin{array}{c}\text { Weight of Sandy Clay Soil } \\
(\mathbf{k g})\end{array}$ \\
\hline \multirow{2}{*}{16} & 5 & 659.16 \\
& 10 & 655.93 \\
32 & 15 & 652.69 \\
\hline \multirow{2}{*}{48} & 5 & 660.55 \\
& 10 & 658.70 \\
& 15 & 656.85 \\
\hline
\end{tabular}

Calculation Result 5. 


\subsection{Calibration Thomson Door}

To enter the desired flow rate, the first thing that needs to be done is to determine the flow coefficient

Determination of the flow rate coefficient is done by observing the flow rate through the Thomson door. Observations are made repeatedly, so that from these observations the magnitude of the Cd flow coefficient can be calculated, as in Table 2 below:

Table 2. Determination of the discharge coefficient of $\mathrm{Cd}$

\begin{tabular}{|c|c|c|c|c|}
\hline Number & $\begin{array}{c}\text { Water } \\
\text { Level (m) }\end{array}$ & $\begin{array}{c}\text { Period } \\
\text { (sec) }\end{array}$ & $\begin{array}{c}\text { Water } \\
\text { Volume } \\
(\mathrm{ml})\end{array}$ & $\begin{array}{c}\text { Water } \\
\text { Volume } \\
\left(\mathbf{m}^{3}\right) \\
\end{array}$ \\
\hline & $\mathrm{H}$ & $\mathrm{T}$ & & V \\
\hline 1 & 0.035 & 300 & 127000 & 0,127 \\
\hline 2 & 0.035 & 300 & 127800 & 0,1278 \\
\hline 3 & 0.035 & 300 & 127000 & 0,127 \\
\hline 4 & 0.035 & 300 & 128100 & 0,1281 \\
\hline 5 & 0.035 & 300 & 129000 & 0,129 \\
\hline \multicolumn{4}{|c|}{ V Average } & 0,12778 \\
\hline \multicolumn{4}{|c|}{$\mathrm{Q}\left(\mathrm{m}^{3} / \mathrm{sec}\right)$} & 0,000426 \\
\hline
\end{tabular}

Result: Laboratory Test

$$
\begin{gathered}
Q=\frac{8}{15} C_{d} \operatorname{tg} \frac{\propto}{2} \sqrt{2 g} H^{5 / 2} \\
0,0004259 \times 15 \\
C d=0,787
\end{gathered}
$$

With the value of $\mathrm{Cd}=0.787$, it can be calculated that the water level at the Thomson $(\mathrm{H})$ gate is in accordance with the desired flow rate. The water level at the Thomson door is shown in Table 3.

Table 3. Water Level at Thomson Door

\begin{tabular}{cccc}
\hline Number & $\begin{array}{c}\text { Flow Debit } \\
\left(\mathbf{c m}^{3} / \mathbf{s e c}\right)\end{array}$ & $\begin{array}{c}\text { Flow } \\
\text { Coeficient }\end{array}$ & $\begin{array}{c}\text { Water Level on } \\
\text { Thomson Door } \\
(\mathbf{c m})\end{array}$ \\
\hline & & & \\
\hline 1 & $\mathrm{Q}$ & $\mathrm{Cd}$ & $\mathrm{H}$ \\
\hline 2 & 2500 & & 7,1 \\
3 & 1500 & 0,787 & 5,8 \\
\hline
\end{tabular}

Calculation Result

\subsection{Determination of Infiltration Debit}

From the research results the effect of the distance of the pore cylinder holes on the infiltration rate. For sandy clay soil samples with a flow rate of $400 \mathrm{~cm}^{3} / \mathrm{s}, 1500 \mathrm{~cm}^{3} / \mathrm{s}$ and $2500 \mathrm{~cm}^{3} / \mathrm{s}$, in three variations of the hole spacing, namely $16 \mathrm{~cm}, 32 \mathrm{~cm}$ and $48 \mathrm{~cm}$ with a pore cylinder height of $15 \mathrm{~cm}, 10 \mathrm{~cm}$ and $5 \mathrm{~cm}$. shown in Table 4, Fig. 6, Fig. 7

\begin{tabular}{|c|c|c|c|c|}
\hline \multirow{2}{*}{$\begin{array}{c}\text { Pore } \\
\text { Cylinder } \\
\text { Height (cm) }\end{array}$} & \multirow{2}{*}{$\begin{array}{c}\text { Hole } \\
\text { Spacing } \\
\text { (cm) }\end{array}$} & \multicolumn{3}{|c|}{$\begin{array}{c}\text { Infiltration Debit }\left(\mathrm{cm}^{3} / \mathrm{sec}\right) \text { Based } \\
\text { on Flow Debit }\left(\mathrm{cm}^{3} / \mathrm{sec}\right)\end{array}$} \\
\hline & & 400 & 1500 & 2500 \\
\hline \multirow{3}{*}{15} & 16 & 35,080 & 34,611 & 34,091 \\
\hline & 32 & 31,930 & 30,881 & 29,808 \\
\hline & 48 & 31,352 & 29,885 & 29,679 \\
\hline \multirow{3}{*}{10} & 16 & 33,969 & 32,219 & 32,122 \\
\hline & 32 & 29,774 & 28,615 & 28,230 \\
\hline & 48 & 29,008 & 28,078 & 27,046 \\
\hline \multirow{3}{*}{5} & 16 & 31,389 & 30,914 & 30,522 \\
\hline & 32 & 26,993 & 26,726 & 24,867 \\
\hline & 48 & 26,547 & 25,638 & 23,987 \\
\hline
\end{tabular}

and Fig. 8.

Table 4. Infiltration Discharge Parameters for Sandy Clay Soil Samples

Result: Laboratory Research

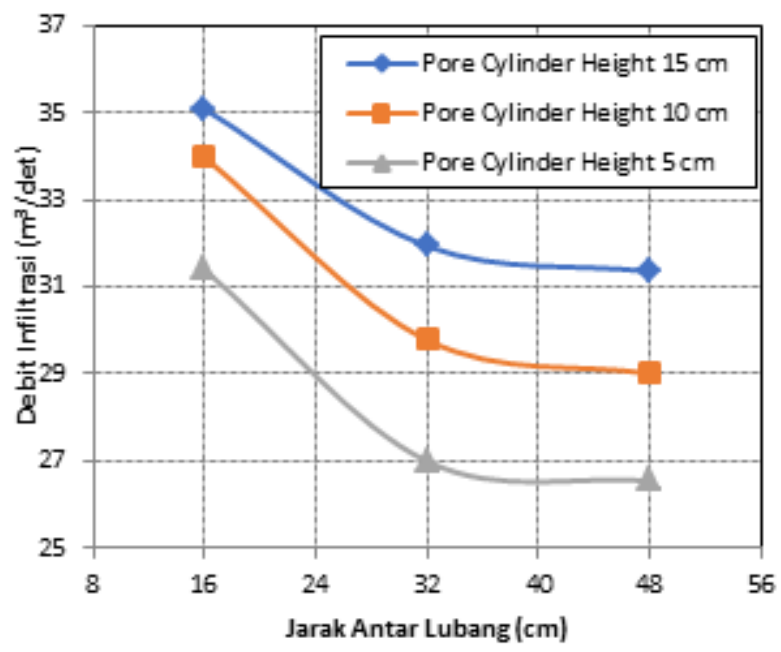

Figure 6. Effect of Pore Cylinder Spacing on Infiltration Discharge with Flow Discharge of $400 \mathrm{~cm}^{3} / \mathrm{sec}$ in Sandy Clay Soil Samples

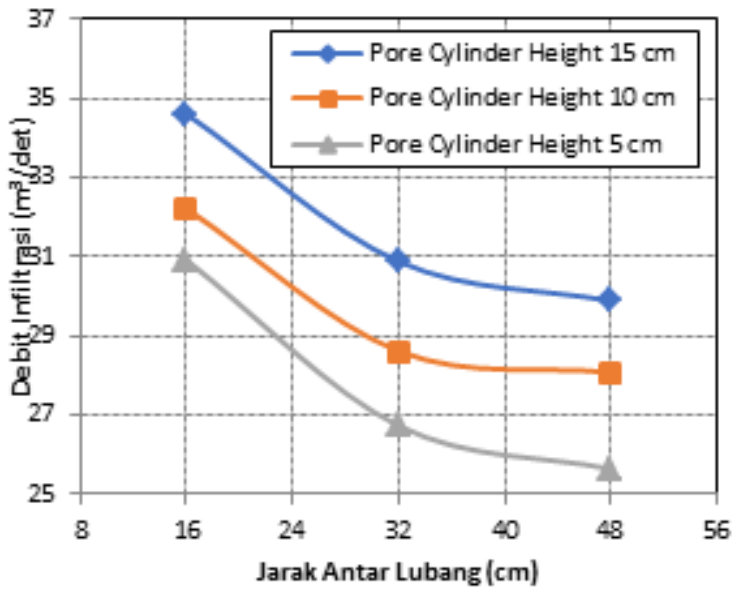

Figure 7. The Effect of Pore Cylinder Hole Distance on Infiltration Discharge with a Flow Rate of $1500 \mathrm{~cm}^{3} / \mathrm{sec}$ in Sandy Clay Soil Samples 


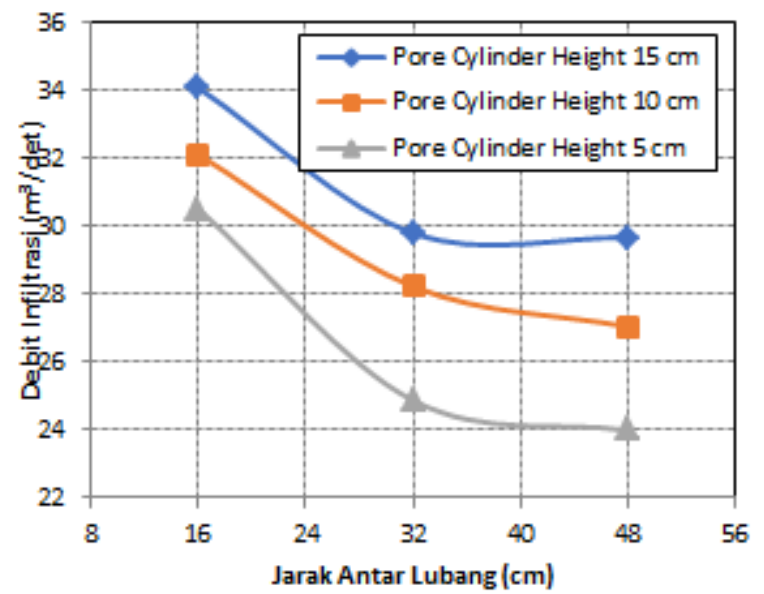

Figure 8. The Effect of Pore Cylinder Hole Distance on Infiltration Discharge with a Flow Rate of $2500 \mathrm{~cm} 3$ / sec in Sandy Clay Soil Samples

\section{Closing}

\subsection{Conclusions}

The effect of the hole distance on the infiltration discharge is very large, the closer the pore cylinder hole distance, the greater the infiltration discharge that occurs. The height of the pore cylinder also affects the infiltration discharge, the higher the pore cylinder, the greater the resulting infiltration discharge.

\subsection{Suggestion}

For further research, it is recommended that the soil used be more varied, therefore it makes further data comparisons.

\section{Acknowledgments}

Appreciation is extended to the ministry of Education and culture for the help of applied research Costs superior college.

\section{REFERENCES}

[1] Ashdak, Chay. 2004. Hydrology and Watershed
Management. Gadjah Mada Press. Yogyakarta

[2] Bowles, Joseph E. 1989. Physical and Geotechnical Properties of Soil (Soil Mechanics). Hainim, Ir.JK, translator: Erlangga. Translation from: McGraw-Hill, Inc

[3] Brata RK, 2008. Modified Biopore Infiltration Hole. Jakarta: Penebar Swadaya

[4] Darwia, Seva, Ichwana, and Mustafril. 2017. Infiltration Rate of Biopore Infiltration Hole (LRB) Based on Types of Organic Material as Water and Soil Conservation Efforts. Unsyiah Agricultural Student Scientific Journal, 2 (1), 1-10.

[5] Daud Fenti S. 2015. A Model of Porous Drainage Channels to Reduce Urban Flood Inundation.

[6] Fuadi, Azhar and Terunajaya. The Influence of Infiltration and Permeability on Infiltration Wells in Housing Areas (Case Study: Taman Setia Budi Indah II, Medan). Pages $1-10$.

[7] Harisuseno, Donny, Evi Nur Cahya, Reta L. Puspasari. Study of the Effect of Physical Properties of Soil on Characteristics of Infiltration Rate. Pages 1-7

[8] Hadisusanto Nugroho. 2011. Applications of Hydrology. Jogja Main Media. Yogyakarta

[9] Indarto. 2010. Basic Hydrology Theory and Examples of Hydrological Model Applications. Earth Literacy. Jakarta

[10] Kuncoro Jati Munaljid, Lily Montarcih L, Runi Asmaranto, and Dian Noorvy K. 2015. Application of Infiltration Model on Soil with Kostiyacov Model and Horton Model Using Rainfall Simulator Tool. Scientific Journal of Water Resources Conservation. Pages 1-11.

[11] M. Arsyad, M Thaha, Achmad Zubair, and Siti Nur Athirah. 2015. Effect of Water Level on Infiltration Rate for Sandy Clay Soil Types in Environmentally Friendly Drainage Model. Pages 1-9

[12] Oktawijaya, Domie, Nurhayati, and Azwa Nirmala. Analysis of Maximum Capacity of Drainage Channels Jl. Tanjungpura. Pages 1-10.

[13] Sanjaya, William, Kevin Billy Christian, Danny Gunaran, and Elly Kusumawati. 2017. Measurement of Biopore Infiltration Hole Infiltration Rate

[14] Soepardi G. 1983. Basics of soil science. Bogor. IPB Pr.

[15] Suripin. 2004. Sustainable Drainage Systems. Publisher And Offset. Yogyakarta

[16] Triatmodjo Bambang 2018. Hidrolika 1. Beta Offset. Yogyakarta 